\title{
MEKANISME PENYELESAIAN PERKARA PERSELISIHAN HUBUNGAN INDUSTRIAL DITINJAU DARI UNDANG-UNDANG NOMOR 2 TAHUN 2004 TENTANG PENYELESAIAN PERSELISIHAN HUBUNGAN INDUSTRIAL PADA PENGADILAN NEGERI KLAS IA SAMARINDA
}

\author{
Maryanto dan Wahyuni Safitri \\ mariyantophi@yahoo.com,wahyunibun@uwgm.ac.id \\ Hakim AdHoc PHI Samarinda dan Dosen Fakultas Hukum Universitas Widya Gama \\ Mahakam Samarinda
}

\begin{abstract}
The relation between legal subjects such as person or legal entity in a case, frequently generates dispute. Along with the complexity of social life, then, the more parties are involved in the dispute, the wider scope of the dispute case. One of the concerned dispute in the society is Industrial Relations Disputes that become the competence of Industrial Relations Court. Since 2015, The Act No. 2/2004 about Industrial Relations Dispute Settlement has enforced effectively, it still has many weaknesses, wether from practical or regulation aspects. The legal problems of its Act cause the settlement of Industrial Relations Dispute become less effective and efficient, also hamper the principle of constante justitite (principle of rapid, fair and easy trial).

The research concluded that the practical/operational level of the Judges Panel in examining and adjudicating the cases of Industrial Relations Dispute in Industrial Relations Court of Samarinda, which tend to apply the general civil procedure law, from the examination of legal standing of the parties, exception, interlocutory decision, replik, duplik, writen proof, the witnesses, experts/professional witnesses, conclusion and verdict. This procedures only prolong the examination and trial process to settle the case of Industrial Relations Dispute. Therefore, the SOP (Standard Operational Procedure) of the settlement of Industrial Relations Dispute cannot be well-implemented yet as the mandate of the law.
\end{abstract}

Keywords: Industrial Relations Dispute, Industrial Relations Dispute Court, Standard Operational Procedure (SOP)

\section{PENDAHULUAN}

Perselisihan atau perbedaan dalam suatu perkara dimungkinkan terjadi dalam setiap hubungan antar manusia, bahkan subjek hukum lainnya seperti badan hukum, maka para pihak yang terlibat di dalam perselisihan semakin banyak. Dengan semakin kompleksnya corak kehidupan masyarakat, maka ruang lingkup kejadian atau peristiwa perselisihanpun meliputi ruang lingkup semakin luas, diantaranya yang sering mendapat perhatian masyarakat adalah perselisihan hubungan industrial. Perselisihan hubungan industrial biasanya terjadi antara pekerja/buruh dan perusahaan atau antara organisasi buruh dengan organisasi perusahaan. Dari sekian banyak kejadian atau peristiwa konflik atau perselisihan yang penting adalah solusi 
untuk penyelesaiannya yang harus betulbetul objektif agar terwujud pengadilan cepat, tepat, adil dan murah.

Penyelesaian perselisihan pada dasarnya dapat diselesaikan oleh para pihak sendiri, dan dapat juga diselesaikan dengan hadirnya pihak ketiga, baik yang disediakan oleh negara atau para pihak sendiri. Dalam masyarakat modern yang diwadahi organisasi kekuatan publik berbentuk negara, forum resmi yang disediakan oleh negara untuk penyelesaian perkara atau perselisihan biasanya adalah lembaga peradilan.

Pengadilan Hubungan Industrial (PHI) merupakan terminologis yang dikenal dalam Undang-Undang (UU) Nomor 2 Tahun 2004 tentang Penyelesaian Perselisihan Hubungan Industrial (PPHI) dan UU Nomor 13 Tahun 2003 tentang Ketenagakerjaan. UU ini disahkan pada tanggal 14 Januari 2004, dan berdasarkan Peraturan Pemerintah Pengganti UndangUndang (PERPU) Nomor 1 Tahun 2005 eksistensi PHI mulai efektif sejak tanggal 14 2006. Konsekuensi logis adanya UU ini, UU terdahulu mengenai perburuan yaitu UU Nomor 22 Tahun 1957 tentang Penyelesaian Perselisihan Perburuan dan UU Nomor 12 Tahun 1964 tentang Pemutusan Hubungan Kerja di Perusahaan Swasta, tidak berlaku kembali.

Semenjak berlaku efektif pada tahun 2015, UU PPHI dianggap masih memiliki banyak kelemahan baik dari aspek pelaksanaan maupun secara regulative. Di dalam pelaksanaannya timbul permasalahan hukum yang mengakibatkan proses penyelesaian perselisihan industrial yang berlangsung lama dan ini berarti mahal. Hal ini dapat disebabkan antara lain : Pertama keberdaan Pengadilan Hubungan Industrial yang hanya ada pada Pengadilan Negeri tingkat ibu kota provinsi yang rata-rata jumlah perkara perdata, pidana, tindak pidana korupsi, perselisihan hubungan industrial secara keseluruhan setiap tahunnya lebih dari 2.000 perkara sedangkan jumlah hakim yang memeriksa dan mengadili perkara-perkara hanya berkisar antara 15 sampai dengan 20 orang untuk setiap Pengadilan Negeri sehingga kebutuhan hakim tidak proporsional/ideal dengan jumlah perkara yang ditangani. Kedua Pelaksanaan penyelesaian Pengadilan Hubungan Industrial masih menggunakan hukum acara perdata pada hukum acara perdata peradilan umum. Sehingga Majelis Hakim yang memeriksa dan mengadili perkara perselisihan hubungan industrial cenderung menggunakan acara perdata umum dimulainya dengan pemeriksaan legal standing para pihak gugatan, jawaban (eksepsi), putusan sela, replik, duplik, pembuktian tertulis, pemeriksaan saksi, pemeriksaan ahli, kesimpulan, dan putusan dengan demikian hal tersebut memperpanjang proses persidangan.

Pengertian Perselisihan Hubungan Industrial sebagaimana ketentuan Pasal 1 angka1 UU Nomor 2 Tahun 2004 dan Pasal 1 angka 22 UU Nomor 13 Tahun 2003 adalah :

"Perselisihan hubungan industrial adalah perbedaan pendapat yang mengakibatkan pertentangan antara pengusaha atau gabungan pengusaha dengan pekerja/buruh atau erikat pekerja/serikat buruh karena adanya perselisihan mengenai hak, perselisihan kepentingan, dan perselisihan pemutusan hubungan kerja serta perselisihan antar serikat pekerja/serikat buruh hanya dalam satu perusahaan".

Berdasarkan pengertian tersebut di atas, diperoleh pemahaman bahwa timbulnya perselisihan hubungan industrial disebabkan adanya pertentangan pendapat antara pekerja/buruh dengan pengusaha yang merupakan obyek perselisihan hubungan industrial yaitu adanya 
perselisihan hak, perselisihan kepentingan, perselisihan karena pemutusan hubungan kerja (PHK) dan perselisihan antar serikat pekerja/serikat buruh dalam satu perusahaan.

Adapun yang menjadi subyek perselisihan hubungan industrial ${ }^{1}$ adalah:

1. Pengusaha/gabungan pengusaha, yang dimanifestasikan sebagai :

a. orang perseorangan, persekutuan, atau badan hukum yang menjalankan suatu perusahaan milik sendiri;

b. orang perseorangan, persekutuan, atau badan hukum yang secara berdiri sendiri menjalankan perusahaan bukan miliknya;

c. orang perseorangan, persekutuan, atau badan hukum yang berada di Indonesia mewakili perusahaan sebagaimana dimaksud dalam huruf a dan $b$ yang berkedudukan di luar wilayah Indonesia.

2. Pekerja/buruh adalah setiap orang yang bekerja dengan menerima upah atau imbalan dalam bentuk lain.

3. Serikat pekerja/serikat buruh.

4. Usaha-usaha social dan usaha-usaha lain yang mempunyai pengurus dan mempekerjakan tenaga kerja dengan membayar upah atau dalam bentuk lainya.

Ketentuan UU Nomor 2 Tahun 2004 tentang Penyelesaian Perselisihan Hubungan Industrial hakikatnya telah memberikan beberapa alternative sebagai solusi bagaimana penyelesaian perkara perselisihan hubungan industrial melalui PHI. Ada 2 (dua) bentuk polarisasi penyelesaian perselisihan hubungan industrial menurut ketentuan UU Nomor 2

1 Lilik Mulyadi dan Agus Subroto, 2011, Penyelesaian Perkara Pengadilan Hubungan Industrial Dalam Teori Dan Praktek, Bandung, P.T.ALUMNI, Hal. 32-34.
Tahun 2004, yaitu secara nonlitigasi yaitu dapat dilakukan melalui perundingan bipartite, Tripartit melalui lembaga Mediasi, Konsiliasi dan Arbiter, dan secara litigasi yaitu melalui Pengadilan Hubungan Industrial $^{2}$.

Dengan diberlakunya UU Nomor : 2 Tahun 2004, Pengadilan Hubungan Industrial pada Pengadilan Negeri Samarinda memiliki wilayah hukum untuk sementara ini meliputi seluruh wilayah Propinsi Kalimantan Timur dan Kalimantan Utara, dan merupakan lembaga penyelesaian secara litigasi yang mempunyai kewenangan untuk memeriksa dan mengadili perkara perselisihan Hubungan Industrial atau Perselisihan Perburuhan yang sebelumnya menjadi beban tugas Panitia Penyelesaian Perselisihan Perburuhan Daerah (P4D) menjadi wewenang mutlak Pengadilan Hubungan Industrial. Sesuai dengan ketentuan Pasal 56 Undang-undang NomoR: 2 Tahun 2004 disebutkan Pengadilan Hubungan Industrial bertugas dan berwenang memeriksa dan memutus :

1. di tingkat pertama mengenai perselisihan hak;

2. di tingkat pertama dan terakhir mengenai perselisihan kepentingan;

3. di tingkat pertama mengenai perselisihan pemutusan hubungan kerja;

4. di tingkat pertama dan terakhir mengenai perselisihan antar serikat pekerja/serikat buruh dalam satu perusahaan;

Hukum acara yang berlaku bagi Pengadilan Hubungan Industrial adalah Hukun Acara Perdata yang berlaku pada pengadilan dalam lingkungan Peradilan Umum, kecuali yang diatur secara khusus

2 Ibid, hlm 59. 
dalam UU Nomor : 2 Tahun 2004. Hal ini secara tegas disebutkan dalam Pasal 57 UU Nomor : 2 Tahun 2004, dengan demikian maka ketentuan ini mengatur ketentuan dan prosedur beracara yang merupakan ketentuan khusus (lex specialis) dan ketentuan hukum acara perdata yang berlaku umum sehingga hukum acara perdata yang umum hanya berlaku apabila tidak diatur dalan undang-undang khusus tersebut.

Satu hal yang menjadi karakter khusus dalam hukum acara Pengadilan Hubungan Industrial ialah penentuan secara tegas mengenai jangka waktu penyelesaian perkara dalam waktu yang relative singkat. Untuk perkara Perselisihan Hubungan Industrial ditingkat pertama, UU PPHI telah membatasi jangka waktu pemberian putusan paling lambat 50 (lima puluh) hari terhitung sejak sidang pertama.

Salah satu ciri khusus Pengadilan Hubungan Industrial adalah pembatasan jangka waktu penyelesaian perkara yang ditentukan dengan tegas dalam undangundang. Adanya batas waktu yang relative singkat ini mendorong Pengadilan Hubungan Industrial untuk berusaha semaksimal mungkin membuat pelayanan administrasi perkara lebih efektif dan efisien. Dalam rangka menciptakan mekanisme penyelesaian perkara yang cepat, tepat, adil dan murah.

Terhadap mekanisme penyelesaian perkara yang cepat, tepat, adil dan murah, penulis ingin meneliti terhadap masalah tersebut dengan membandingkan antara das sollen yaitu segala keharusan-keharusan yang berupa teori-teori normative dan sealigus norma-norma teoritis yang secara idial wajib dilaksanakan, dengan das sein yaitu segala sesuatu yang merupakan kondisi kenyataan yang ada dari pelaksanaan teori dan norma das sollen tersebut.
Perbedaan antara das sollen dan das sein inilah yang menyebabkan terjadinya masalah yang penulis ingin teliti dari pemilihan judul Mekanisme penyelesaian perkara perselisihan hubungan industrial ditinjau dari Undang-Undang Nomor 2 tahun 2004 Tentang Penyelesaian Perselisihan Hubungan Industrial di Pengadilan Negeri Klas IA Samarinda.

\section{RUMUSAN MASALAH}

Berdasarkan uraian sebagaimana telah dijelaskan dalam latar belakang diatas, maka penulis merumuskan masalah yang diangkat dalam penulisan ini adalah sebagai berikut:

1. Bagaimana mekanisme penyelesaian perkara perselisihan hubungan industrial ditinjau dari UndangUndang Nomor 2 tahun 2004 Tentang Penyelesaian Perselisihan Hubungan Industrial di Pengadilan Negeri Klas IA Samarinda?

2. Faktor-faktor apa yang menjadi kendala dalam proses penyelesaian perkara perselisihan hubungan industrial di Pengadilan Hubungan Industrial pada Pengadilan Negeri Klas IA Samarinda?

\section{METODE PENELITIAN}

Jenis penelitian hukum yang digunakan dalam penulisan ini adalah penelitian hukum normatif yaitu penelitian yang memusatkan dilakukan dengan cara meneliti bahan hukum primer, bahan hukum sekunder dan bahan hukum tertier. Guna untuk mendukung penulisan maka penelitian hukum normatif ini dibantu dengan penelitian lapangan guna mendapatkan data yang diperlukan dan segala sesuatu yang berkaitan dengan administrasi penyelesaian perkara perselisihan hubungan industrial pada Pengadilan Negeri Klas IA Samarinda. 
Dalam suatu penelitian mutlak diperlukan kecermatan dalam memilih metode yang dipergunakan. Metode penelitian dipilih berdasarkan dan mempertimbangkan keserasian dengan obyek serta sesuai dengan tujuan. Memilih metode yang benar atau tepat akan memperoleh hasil yang memuaskan. Metode yang penulis pergunakan dalam penelitian ini adalah yuridis normatif ditunjang dengan penelitian lapangan.

Sumber Data yang digunakan dalam Penelitian adalah bahan hukum Primer yang terdiri dari serangkaian aturan yang tertulis dan terkait dengan permasalahan yang diangkat dalam penelitian ini, bahan hukum sekunder yaitu bahan hukum yang memberikan penjelasan terhadap hukum primer baik literature, jurnal, dan majalah maupun artikel terkait dengan permasalahan tersebut, dan bahan hukum tersier yaitu bahan hukum yang memberikan penjelasan baik terhadap bahan hukum primer maupun bahan hukum sekunder yaitu berupa kamus hukum dan kamus Bahasa Indonesia.

Analisis data yang digunakan dalam penelitian ini metode analisis deskriptif kualitatif, yaitu sebagai prosedur penelitian yang menghasilkan data deskriptif, berupa kata-kata tertulis atau lisan dari orang-orang dan perilaku yang dapat diamati. Pendekatan ini diarahkan pada latar belakang dari individu tersebut secara holistik (utuh). Jadi dalam hal ini, tidak boleh mengisolasikan individu atau institusi ke dalam variabel atau hipotesis, tetapi perlu memandangnya sebagai bagian dari suatu keutuhan.

\section{PEMBAHASAN}

A. Mekanisme penyelesaian perkara ketenagakerjaan pada Pengadilan Hubungan Industrial di Pengadilan Negeri Samarinda

\section{ditinjau dari Undang-Undang Nomor 2 tahun 2004 Tentang Penyelesaian Perselisihan \\ Hubungan Industrial.}

\section{Susunan Pengadilan Hubungan Industrial Pada Pengadilan Negeri Klas IA Samarinda.}

Pengadilan Negeri sebagai pengadilan tingkat pertama dan dibentuk dengan Keputusan Presiden (Pasal 6 huruf a dan Pasal 7 Undang-Undang Nomor 49 Tahun 2009) dengan tugas dan kewenangan memeriksa, memutus, dan menyelesaikan perkara pidana dan perkara perdata di tingkat pertama (Pasal 50 Undang-Undang Nomor 49 Tahun 2009). Adapun mengenai tempat kedudukan pengadilan negeri pada prinsipnya berada di ibu kota kabupaten/kota dan daerah hukumnya meliputi wilayah kabupaten/kota (Pasal 4 ayat (1) Undang-Undang Nomor 49 Tahun 2009).

Pada praktiknya dengan melihat volume perkara dan jumlah hakim maka pengadilan negeri dapat diklasifikasikan menjadi Pengadilan Negeri Kelas I dan Kelas II. Pada Pengadilan Negeri Kelas I dibagi lagi menjadi Pengadilan Negeri Kelas IA dan Pengadilan Negeri Kelas IB dengan catatan untuk setiap provinsi selalu terdapat Pengadilan Negeri Kelas IA pada ibu kota provinsinya dan Pengadilan Negeri Kelas IA Khusus yang tidak terletak pada ibu kota provinsinya.

$$
\text { Pengadilan Negeri Kelas IA }
$$
Samarinda adalah Pengadilan Negeri yang diberikan kewenangan berdasarkan undangundang untuk melaksanakan tugas dan kewenangan memeriksa, memutus, dan menyelesaikan perkara pidana dan perkara perdata di tingkat pertama mengenai Peradilan Umum (Perdata, Pidana, Anak, Tipilu, Lingkungan), Pengadilan Hubungan Industrial dan Pengadilan Tindak Pidana Korupsi. 
Berdasarkan ketentuan Pasal 10 ayat (1) Undang-Undang Nomor 49 Tahun 2009 maka susunan Pengadilan Negeri terdiri atas pimpinan, hakim anggota, panitera, sekretaris, dan juru sita, Mengenai tugas para hakim dalam teknis yustisial adalah memeriksa dan mengadili perkara dan dalam teknis administratif (nonyustisial) adalah melakukan tugas administrasi sebagai hakim pengawas bidang-bidang administrasi pembantu ketua (Keputusan Mahkamah Agung Nomor KMA/OO6/SK/Ill/1994, Keputusan Ketua Mahkamah Agung Nomor KMA/005/SK/III1994, dan Keputusan Ketua Mahkamah Agung Nomor KMA/OOB/SK/II/ 1992) ${ }^{3}$.

a) Profil

\section{Negeri/Hubungan Industrial Samarinda}

Pada tahun 1975 Kantor Pengadilan Negeri Samarinda didirikan serta diresmikan pada tahun berikutnya tepatnya pada tahun 1976. Mulanya Pengadilan Negeri Samarinda hanya 1 (satu) buah gedung saja (dikenal gedung lama yang sekarang dipergunakan untuk gedung Pengadilan Hubungan Industrial) namun seiring dengan perkembangan jaman Pengadilan Negeri Samarinda yang lama tersebut kondisi gedung sudah tidak memadai lagi dimana posisi lantai gedung lebih rendah dari badan jalan M.Yamin sehingga setiap hujan lantai gedung terendam air (banjir) dan pada tahun 2003 dibangun sebuah gedung kantor Pengadilan Negeri Samarinda berlantai 2 (dua) yang terletak disamping kiri gedung lama (ex lapangan tenis) kawasan Jl.M.Yamin dari anggaran APBN (DIPA Tahun 2003).

Kemudian berdasarkan UU RI Nomor 2 tahun 2004 tentang penyelesaian Perselisihan Hubungan Industrial ; UU RI

3 Lilik Mulyadi, 2015, Putusan Hakim dalam Hukum Acara Perdata Indonesia, Bandung, Citra Aitya Bakti, Hal.70.
Nomor 164 tahun 1970 tentang Ketentuan Pokok Kekuasaan Kehakiman jo UU RI No.35 tahun 1999 jo UU RI No.04 Tahun 2004 tentang Kekuasaan Kehakiman ;UU RI No.02 Tahun 1996 jo UU RI No.08 tahun 2004 tentang Peradilan Umum di Kota Samarinda telah terbentuk Pengadilan Hubungan Industrial yang berkantor di Gedung lama Pengadilan Negeri Samarinda dimana Ketua Pengadilan Negeri Samarinda serta Panitera Pengadilan Negeri Samarinda bertindak sebagai Ketua Pengadilan Hubungan Industrial dan Panitera Pengadilan Hubungan Industrial Samarinda.

Pengadilan Negeri Samarinda adalah pelaksana Kekuasaan Kehakiman pada peradilan umum tingkat pertama, yang bertugas menyelenggarakan peradilan guna menegakkan hukum dan keadilan berdasarkan Pancasila, dengan tugas pokok menerima, memeriksa dan mengadili serta menyelesaikan setiap perkara yang diajukan kepadanya termasuk di dalamnya bertugas dan berwenang memeriksa, memutus dan menyelesaikan setiap perkara Perselisihan Hubungan Industrial (PHI) yang diajukan kepadanya sesuai dengan kewenangannya di tingkat pertama dan tugas lain yang diberikan kepadanya berdasarkan peraturan perundang-undangan. 
a) Struktur Organisasi Pengadilan Negeri / Hubungan Industrial / Tipikor Klas I.A Samarinda ${ }^{4}$

STRUKTUR ORGANISASIPENGADILAN NEGERI

SAMARINDA

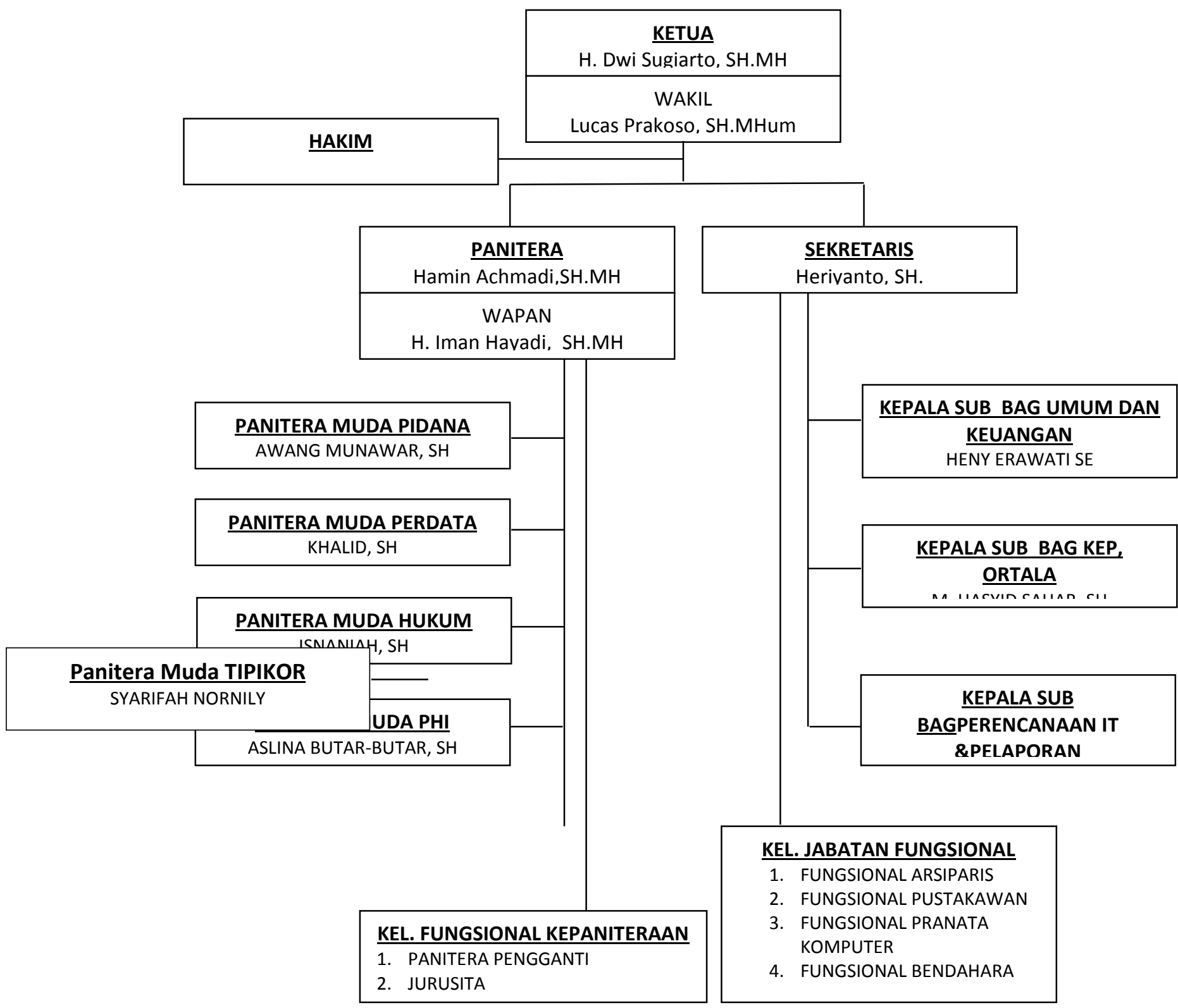

4PN Samarinda, Sistim Informasi Penelusuran Perkara, http:/sipp.pn-samarinda.go.id/2017, diakses tanggal 10 Oktober 2017, 
Ketua dan wakil ketua melaksanakan hal-hal yang telah diuraikan, maka pimpinan para hakim pejabat Kepaniteraan serta Sekretariat, sesuai dengan uraian tugas (job description) masing-masing, dibawah pimpinan dan koordinasi Ketua Pengadilan Negeri. keuangan perdata, bertanggung jawab atas pengurusan berkas perkara, putusan, dokumen, akta, buku daftar, biaya perkara, uang titipan pihak ketiga, surat-surat bukti dan surat. surat lainnya yang disimpan di kepaniteraan, melaksanakan eksekusi perkara perdata yang diperintahkan oleh ketua pengadilan, serta membuat akta dan salinan putusan. Selain itu, panitera juga mengikuti jalannya persidangan dan mencatat secara teliti hal itu (Pasal 58 dan 59 Undang-Undang Nomor 49 Tahun 2009, Pasal 63 RO). serta membuat berita acara (proses verbal) sidang pengadilan dan ditandatangani bersama dengan hakim ketua sidang (Pasal 186 HIR, Pasal 197 RBg.). Karena banyaknya tugas seperti itu, maka dalam praktiknya tugas dalam persidangan lazimnya dilakukan oleh panitera Pengganti (PP).

Di samping hakim dan Panitera, juga dikenal adanya juru sita (deur waarder) dan juru sita pengganti (Pasal 39 UndangUndang Nomor 49 Tahun 2009). Pada prinsipnya tugas juru sita melaksanakan semua perintah yang diberikan oleh ketua pengadilan, ketua sidang, dan atau panitera. Selanjutnya terhadap unsur pimpinan pengadilan negeri terdiri atas seorang ketua dan seorang wakil ketua (Pasal 11 UndangUndang Nomor 49 Tahun 2009). Kemudian. berdasarkan ketentuan Pasal 64 UndangUndang Nomor 49 Tahun 2009 maka tugas dan tanggung jawab serta tata kerja kepaniteraan pengadilan diatur lebih lanjut oleh ketua Mahkamah Agung dan Menteri
Kehakiman Republik Indonesia telah dikeluarkan Surat Keputusan tentang Organisasi dan Tata Kerja Sekretariat/Kepaniteraan Pengadilan Negeri dan Pengadilan Tinggi, yaitu Keputusan Menteri Kehakiman Republik Indonesia Nomor M.08-PR.07.02 Tahun 1989 tanggal 19 Desember 1989 dan Surat Keputusan Ketua Mahkamah Agung Republik Indonesia Nomor KMA/003/SK/11/1992 tanggal 24 Februari 1992.

Dalam melaksanakan tugasnya, ketua pengadilan negeri mengadakan pengawasan atas pelaksanaan tugas dan tingkah laku hakim, panitera, sekretaris, dan juru sita di daerah hukumnya. Dalam melaksanakan pengawasan, ketua pengadilan negeri dapat memberi petunjuk, teguran, dan peringatan yang dipandang perlu. Pengawasan tersebut tidak boleh mengurangi kebebasan hakim dalam rnemeriksa dan memutus perkara (Pasal 53 ayat (1), (3), dan (4) UndangUndang Nomor 49 Tahun 2009 dan Pasal 1 Keputusan Ketua Mahkamah Agung Republik Indonesia Nomor KMA/006/SK/111/1994 tanggal 31 Maret 1994 tentang Pengawasan dan Evaluasi atas Hasil Pengawasan oleh Pengadilan Tingkat Banding dan Pengadilan Tingkat Pertama, Sedangkan pengawasan yang dilakukan oleh ketua pengadilan tersebut kepada para hakim dalam melaksanakan tugasnya itu dapat berbentuk secara tertulis ataupun lisan (Pasal 5 huruf (a) dan (b) Keputusan Ketua Mahkamah Agung Republik Indonesia Nomor KMA/006/SK/11ll 1994 tanggal 31 Maret 1994).

Pengadilan Hubungan Industrial merupakan pengadilan khusus yang berada pada lingkungan peradilan umum, yang dibentuk pada Pengadilan Negeri (PN) dan pada Mahkamah Agung (MA). Pembentukan Pengadilan Hubungan Industrial adalah didasarkan pada ketentuan Pasal 55 Undang-Undang Nomor 2 Tahun 2004. Keberadaan Pengadilan Hubungan 
Industrial yang dirasakan belum dapat menjadi lembaga yang dapat memberikan keadilan untuk pekerja/buruh. Hal tersebut disebabkan adanya perubahan paradigma penyelesaian sengketa perburuhan dari yang dulu sarat dengan norma dan institusi publik kini bergeser menjadi domain hukum perdata. ${ }^{5}$ Diciptakan sebagai sebuah "pengadilan khusus" dalam sistem peradilan umum, Pengadilan Hubungan Industrial menggunakan sistem beracara dalam HIR dan RBg, layaknya pengadilan umum. Hanya ada beberapa pengecualian, namun secara umum mulai dari pendaftaran gugatan hingga eksekusi putusan, mengikuti sistem yang ada pada HIR dan RBg. Apabila dilihat dari ketentuan yang ada maka sebagai salah satu jaminan agar tercapai penyelesaian yang cepat, tepat, adil dan murah, penyelesaian perselisihan hubungan industrial (PPHI) melalui Pengadilan Hubungan Industrial yang berada pada lingkungan peradilan umum dibatasi proses dan tahapannya, dengan tidak membuka kesempatan untuk mengajukan upaya banding ke Pengadilan Tinggi. Putusan Pengadilan Hubungan Industrial yang menyangkut perselisihan hak dan penelisihan PHK dapat langsung dimintakan kasasi ke Mahkamah Agung. Sedangkan putusan Pengadilan Hubungan Industrial yang menyangkut perselisihan kepentingan dan perselisihan antar SP/SB dalam satu perusahaan, merupakan putusan tingkat pertama dan terakhir yang tidak dapat dimintakan kasasi ke Mahkamah Agung.

Susunan Pengadilan Hubungan Industrial pada Pengadilan Negeri Kelas IA Samarinda terdiri dari:
a. Hakim
b. Hakim Ad Hoc
c. Panitera Muda
d. Panitera Pengganti dan

\footnotetext{
${ }^{5}$ Dalam M.Hadi Shubhan, Keadilan Tak Kunjung Tiba, Jawa Pos Surabaya, 1 Mei 2010.
}

e. Juru Sita Pengganti

Sementara susunan Pengadilan Hubungan Industrial pada Mahkamah Agung terdiri dari :

a. Hakim Agung;

b. Hakim Ad Hoc pada Mahkamah Agung;

c. Panitera.

Hakim Pengadilan Hubungan Industrial diangkat dan dilantik berdasarkan Keputusan Ketua Mahkamah Agung, sedangkan untuk Hakim Ad Hoc diangkat dengan Keputusan Presiden atas usul Ketua Mahkamah Agung dengan masa kerja 5 tahun dan dapat diangkat kembali untuk 1 (satu) kali masa jabatan. Hakim Ad Hoc untuk pertama kali pengangkatannya paling sedikit 5 orang dari unsur Serikat Pekerja/Serikat Buruh dan 5 orang dari unsur Organisasi Pengusaha. Syarat-syarat menjadi hakim ad hoc diatur di dalam Pasal 64 UU No 2 Tahun 2004 tentang PPHI. Berdasarkan data pada Pengadilan Negeri Klas IA Samarinda jumlah Majelis Hakim Ad Hoc yang ada adalah 3 orang dari Hakim karir, 2 orang dari unsur Serikat Pekerja/Serikat Buruh dan 1 orang dari unsur Organisasi Pengusaha, kondisi tersebut menyebabkan penyelesaian perkara hubungan industrial urang efektif dan efisien.

\section{Kewenangan Pengadilan Hubungan Industrial Pengadilan Negeri Samarinda}

Pengadilan Hubungan Industrial pada Pengadilan Negeri Samarinda merupakan salah satu pemegang kekuasaan kehakiman. Kekuasaan kehakiman sendiri adalah kekuasaan negara yang merdeka. Kekuasaan dimaksud dilakukan agar dapat diselenggarakan peradilan guna menegakkan hukum dan keadilan berdasarkan Pancasila, demi terselenggaranya negara hukum di Indonesia. Oleh karena itu, peradilan dilakukan "Demi Keadilan dan Berdasarkan Ketuhanan Yang Maha Esa", sederhana, 
cepat dan biaya ringan. Hal dimaksud sesuai dengan Pasal 29 UUD 1945, yang menentukan bahwa negara berdasarkan atas Ketuhanan Yang Maha Esa, dan negara menjamin kemerdekaan tiap-tiap penduduk untuk memeluk agama masing-masing dan untuk beribadat menurut agamanya dan kepercayaannya. Suatu proses peradilan yang sederhana, dimaksudkan agar pemeriksaan dan penyelesaian perkara dilakukan dengan cara yang efisien dan efektif, dengan biaya ringan sehingga dapat terpikul oleh rakyat.

Pengadilan negeri Samarinda mengadili menurut hukum dengan tidak membeda-bedakan orang. Adalah tugas peradilan untuk membantu pencari keadilan dan berusaha mengatasi segala hambatan dan rintangan untuk dapat tercapainya peradilan yang sederhana, cepat, dan biaya ringan. Oleh karena itu, pengadilan tidak boleh menolak untuk memeriksa, mengadili dan memutus perkara yang diajukan dengan dalih bahwa hukum tidak ada atau kurang jelas, melainkan wajib untuk memeriksa dan mengadili semua perkara yang diajukan (Pasal 1 s/d 5, dan 16 UU No. 4 Tahun 2004). Mengenai kekuasaan pengadilan dalam perkara perdata, oleh undang-undang kekuasaan itu meliputi semua sengketa tentang hak milik atau hak-hak yang timbul karenanya, hutang piutang atau hak-hak keperdataan lainnya (Pasal 2 ayat (l) RO). Untuk Pengadilan Hubungan Industrial pada Pengadilan Negeri Samarinda diberikan kewenangan oleh undang-undang sebagaimana ditentukan dalam Pasal 56 Undang-Undang Nomor 2 Tahun 2004, terbatas dalam mengadili perkara perselisihan hubungan indusrrial yang meliputi perselisihan:

a. Perselisihan Hak di tingkat pertama,

b. Perselisihan PHK di tingkat pertama,

c. Perselisihan Kepentingan di tingkat pertama dan terakhir, dan d. Perselisihan antar SP/SB dalam satu perusahaan di tingkat pertama dan terakhir

Selain memutus perkara yang telah ditetapkan oleh undang-undang Pengadilan Hubungan Industrial berdasarkan Pasal 33 ayat (6). 35 ayat (4), dan 38 UndangUndang Nomor 2 Tahun 2004 juga diberi pula tugas dan wewenang tambahan ${ }^{6}$. yaitu:

a. Mengangkat arbiter apabila para pihak telah memilih penyelesaian melalui arbiter akan tetapi tidak tercapai kesepakatan dalam memilih arbiter yang ada,

b. Memutus tuntutan hak ingkar terhadap arbiter yang diragukan kebebasannya dan akan berpihak dalam mengambil putusan arbitrase, dan

c. Memutus permohonan penarikan diri arbiter, yang tidak disetujui oleh para pihak yang bersengketa.

d. Pengajuan gugatan dalam Pengadilan Hubungan Industrial

Setelah mediasi atau konsiliasi gagal menyelesaikan perselisihan, dan mediator/konsiliator telah menerbitkan anjuran maka salah satu pihak atau kedua belah pihak dapat mengajukan gugatan dengan cara mendaftarkan gugatan ke Pengadilan Hubungan Industrial. Gugatan dibuat rangkap 5 (lima), satu gugatan untuk tergugat, tiga gugatan untuk Majelis Hakim dan sisanya untuk arsip. Petugas Pengadilan memberikan nomor register perkara. Apabila penggugat diwakili oleh kuasa hukum baik kuasa hukum dari advokat/ pengacara maupun organisasi Serikat Pekerja/Serikat Buruh atau Organisasi Pengusaha maka pada saat pendaftaran gugatan harus membawa dan mendaftarkan surat kuasa khusus.

\footnotetext{
${ }^{6}$ Sugeng Santosa PN, 2013, Hukum Acara Pengadilan Hubungan Industrial, Karakteristik dan Praktik di Pengadilan, Gresik, PSHPI, Hal.39.
} 


\section{Ketentuan Hukum Acara Yang diterapkan Hakim Pengadilan Hubungan Industrial.}

Pada bagian ini akan dijelaskan ketentuan hukum acara di Pengadilan Hubungan Industrial yang merupakan karakteristik hukum acara Pengadilan Hubungan Industrial dalam putusan-putusan pengadilan. Karakteristik hukum acara yang yang telah ada dalam putusan-putusan pengadilan baik di Pengadilan Hubungan Industrial Pada Pengadilan Negeri maupun yang telah diputus oleh Mahkamah Agung. Karakteristik yang maksud adalah ${ }^{7}$.:

a. Ketentuan adanya risalah perundingan yang dalam pengadilan adalah berupa risalah penyelesaian melalui mediasi atau konsiliasi

b. Ketentuan tentang legal standing atau kuasa hukum yaitu Serikat Pekerja/Serikat Buruh dan Organisasi Pengusaha dapat bertindak sebagai kuasa hukum, untuk mewakili anggotanya.

c. Ketentuan tentang kompetensi absolut

d. Ketentuan tentang Putusan Sela

e. Ketentuan tentang kompetensi relatif berupa tempat pengajuan gugatan di tempat dimana pekerja/buruh bekerja

f. Ketentuan adanya dismissal process

g. Ketentuan tentang macam-macam perselisihan dan kewenangan penyelesaiannya.

Ketentuan hukum acara tersebut selanjutnya dilaksanakan dengan tahapan proses penyelesaian perselisihan di pengadilan secara sistimatik dapat digambarkan tahapannya sebagai berikut:

a. Pencatatan Gugatan

b. Persiapan Persidangan

c. Penetapan Majelis Hakim

1. Pemeriksaan Gugatan

2. Penetapan Hari Sidang

3. Pemanggilan Para Pihak
4. Sita Jaminan:

a) Sita Revindikator

b) Sita Konservator

d. Proses Persidangan

1. Kehadiran Para Pihak:

a. Tidak Hadirnya Penggugat

b. Tidak Hadirnya Tergugat

c. Para Pihak Hadir

2. Acara Pemeriksaan

a. Upaya Perdamaian

b. Macam-Macam Beracara

1. Dengan Acara Cepat

2. Dengan Acara Biasa

c. Pembacaan Surat Gugatan

d. Jawaban Tergugat

e. Anggapan Tergugat (Replik)

1. Eksepsi mengenai pokok perkara

2. Mengenai pokok perkara

- Menangkal;

- Mengakui

- Memberikan fakta baru

3. Gugatan Balik

4. Permohonan

f. Tanggapan Tergugat

g. Pembuktian

h. Pemanggilan Saksi

i. Kesimpulan

j. Pengambilan Keputusan

4. Kuasa Hukum dalam Beracara pada Pengadilan Hubungan Industrial

Dalam sidang pertama yang ditanya hakim adalah hal-hal administratif yang berkaitan dengan identitas para pihak. seperti surat kuasa khusus, kartu identitas para pihak. kartu pengacara/advokat, Berita Acara Sumpah pengacara/advokad apabila penerima kuasa adalah pengacara/advokat. apabila penerima kuasa adalah pengurus serikat pekerja/serikat buruh maka harus melengkapi fotocopy dan menunjukkan aslinya, berupa :

a. Kartu tanda anggota (KTA) baik penerima kuasa maupun permberi kuasa

\footnotetext{
7 Ibid, HIm 81,
} 
b. Bukti pencatatan dari instansi ketenagakerjaan di mana organisasi serikat pekerja/serikat buruh di tingkat unit maupun di tingkat pengurus serikat pekerja/serikat buruh yang menerima kuasa berada.

c. Susunan pengurus serikat pekerja/serikat buruh yang menunjukkan bahwa penerima kuasa adalah pengurus serikat pekerja/serikat buruh di mana penerima kuasa bergabung dalam arganisasi serikat pekerja/serikat buruh tersebut.

Apabila penerima kuasa adalah organisasi pengusaha maka harus melengkapi fotokopi dan menunjukkan aslinya :

a. Kartu anggota organisasi pengusaha

b. Susunan pengurus organisasi pengusaha yang menunjukkan bahwa penerima kuasa adalah pengurus organisasi pengusaha tersebut.

Apabila penerima kuasa adalah karyawan dari badan hukum perseroan terbatas maka melengkapi fotokopi dan menunjukkan aslinya :

a. Surat kuasa khusus dari Direksi

b. Akte Pendirian Perusahaan

c. Kartu tanda pegawai atau surat tugas dari Direksi.

d. Surat Pengangkatan/SK dari Direksi yang menunjukkan bahwa penerima kuasa adalah benar karyawan di perusahaan tersebut.

Setelah melakukan pemeriksaan identitas para pihak maka hakim menanyakan apakah penggugat akan melakukan perbaikan gugatan atau tidak, kemudian hakim mempersilahkan penggugat untuk membaca gugatannya. Setelah pembacaan gugatan maka hakim amberi kesempatan tergugat untuk menyampaikan jawabannya. Apabila tergugat belum siap dengan jawabannya maka hakim memberi kesempatan tergugat untuk persidangan berikutnya agar menyampaikan dan membacakan jawabannya.

6. Jangka Waktu Pemeriksaan pada Pengadilan Hubungan Industrial

Ketentuan waktu penyelesaian yang harus dilaksanakan/dipatuhi oleh pejabat yang melakukan kekuasaan kehakiman, berupa :

a. Dalam waktu paling lama tujuh hari kerja setelah menerima gugatan, Ketua PN harus sudah menerapkan majelis hakim (Pasal 88 ayat (1) Undang-Undang Nomor 2 Tahun 2004);

b. Dalam waktu paling lambat tujuh hari kerja sejak ditetapkannya majelis hakim, ketua majelis hakim harus sudah melakukan sidang pertama (Pasal 89 ayat (1) Undang-Undang Nomor 2 Tahun 2004);

c. Apabila salah satu pihak tidak dapat menghadiri sidang, hari sidang berikutnya paling lama dilakukan tujuh hari kerja sejak tanggal penundaan (Pasal 93 ayat (1) UndangUndang Nomor 2 Tahun 2004);

d. Dalam waktu paling lama tujuh hari kerja setelah menerima gugatan yang cukup mendesak dari pemohon (pemeriksaan dengan acara cepat), Ketua PN menetapkan dikabulkan atau ditolaknya permohonan tersebut (Pasal 98 ayat (2) Undang-Undang Nomor 2 Tahun 2004) ;

e. Tenggang waktu untuk jawaban dan pembuktian dari kedua belah pihak dalam pemeriksaan dengan acara cepat, tidak boleh melebihi 14 hari kerja (Pasal 99 ayat (2) UndangUndang Nomor 2 Tahun 2004);

f. Majelis hakim wajib memberikan putusan paling lama 50 hari kerja terhitung sejak sidang pertama (Pasal 103 Undang-Undang Nomor 2 Tahun 2004); 
g. Panitera pengganti harus memberikan pemberitahuan putusan paling lama 7 hari kerja setelah putusan dibacakan (Pasal 105 Undang-Undang Nomor 2 Tahun 2004);

h. Panitera muda harus menerbitkan salinan putusan paling lama 14 hari kerja setelah putusan ditandatangani (Pasal 105 Undang-Undang Nomor 2 Tahun 2004);

i. Panitera harus mengirimkan salinan putusan paling lama 7 hari kerja setelah salinan putusan diterbitkan (Pasal 107 UndangUndang Nomor 2 Tahun 2004);

j. Putusan Pengadilan mempunyai kekuatan hukum tetap apabila tidak diajukan kasasi paling lama 14 kerja setelah diputus/diterima putusan (Pasal 110 UndangUndang Nomor 2 Tahun 2004);

k. Sub Kepaniteraan harus sudah menyampaikan berkas permohonan kasasi kepada MA paling lama 14 hari kerja setelah menerima permohonan kasasi (Pasal 112 Undang-Undang Nomor 2 Tahun 2004);

1. Penyelesaian perselisihan hak atau PHK pada MA paling lama 30 hari kerja setelah permohonan diterima (Pasal 115 UndangUndang Nomor 2 Tahun 2004);

m. Dalam hukum acara perdata pada umumnya diatur secara internal berdasarkan SK Ketua MA, kecuali proses kasasi ke MA (Pasal $46 \mathrm{~s} / \mathrm{d} 34$ UU. No. 14 Tahun 1985 jo. UU No. 5 Tahun 2004). Ketentuan tentang sidang yang sah. Undang-Undang Nomor 2 Tahun 2004 menentukan bahwa sidang sah apabila dilakukan oleh majelis hakim (Pasal 92 UndangUndang Nomor 2 Tahun 2004). Dalam hukum acara perdata masih dimungkinkan sidang dengan hakim tunggal berdasarkan izin dari Ketua MA.

n. Tidak adanya upaya hukum banding. Dalam Undang-Undang Nomor 2 Tahun 2004 tidak mengenal adanya upaya hukum banding yang tentu saja hal ini merupakan karakteristik hukum acara di pengadilan hubungan industrial yang berbeda dengan asas hukum acara perdata bahwa Pemeriksaan dalam 2 instansi. Sebagaimana ketentuan dalam Undang-Undang Nomor 2 Tahun 2004 maka terhadap putusan Pengadilan Hubungan Industrial Pada Pengadilan tidak ada upaya banding tetapi hanya dapat dilakukan upaya hukum yaitu melalui kasasi di Mahkamah Agung. Hal ini berbeda dengan asas hukum acara perdata yang berpedoman pada pemeriksaan dalam 2 instansi (Ona'erzoe/e in Twee lmtanties) artinya jika salah satu pihak atau para pihak keberatan dengan putusan pengadilan tingkat pertama maka dapat mengajukan banding ke pengadilan tinggi dan selanjutnya pengadilan tinggi akan memeriksa kembali perkara di pengadilan tingkat pertama.

7. Tata Cara Pemeriksaan Hakim pada Pengadilan Hubungan Industrial

a. Pemeriksaan Isi Gugatan (Dismissal Process)

Dalam persidangan pertama ini hukum acara Pengadilan Hubungan Industrial yaitu tentang ketentuan adanya dismissal proces, sebagaimana dimaksud dalam Pasal 83 ayat (2) Undang-Undang Nomor 2 Tahun 2004 menentukan bahwa Hakim berkewajiban memeriksa isi gugatan dan bila terdapat kekurangan, hakim meminta pengugat untuk menyempurnakan gugatannya, dapat dilakukan tetapi dalam praktik hal tersebut sangat jarang dilakukan 
oleh hakim. Hal inilah yang menurut penulis pada akhir putusan sering muncul putusan "NO" atau "tidak dapat diterima" yang tentunya bertentangan dengan prinsip penyelesaian yang cepat, tepat, adil dan murah. Terhadap ketentuan Pasal 83 Undang-Undang Nomor 2 Tahun 2004 ini dalam praktik di Pengadilan Hubungan Industrial dilaksanakan dengan cara yang berbeda oleh hakim Pengadilan Hubungan Industrial yaitu :

1. Membiarkan gugatan diperiksa apa adanya

2. Mengingatkan para pihak khususnya pihak Penggugat apabila ada ketidaklengkapan atau kurang lengkapnya gugatan.

Praktik Pengadilan Hubungan Industrial yang membiarkan gugatan diperiksa apa adanya tersebut, majelis menganut adanya asas hukum acara perdata yang berlaku di peradilan umum yaitu hakim yang pasif dan akibat dari praktik tersebut maka pada awal berdirinya Pengadilan Hubungan Industrial banyak dihasilkan putusan "tidak dapat diterima" atau biasa disebut putusan "NO (niet onvankelijk verklard)". Asas hakim yang pasif ini dalam praktik menurut penulis telah menimbulkan permasalahan berupa :

Ada tidaknya risalah penyelesaian melalui mediasi atau konsilisasi, sebagaimana ketentuan Pasal 83 ayat (I) Undang-Undang Nomor 2 Tahun 2004.

\section{b. Acara Pemeriksaan Biasa}

Pemeriksaan dengan acara biasa dilakukan terhadap perkara yang dianggap tidak memiliki sifat khusus dan mendesak. Pemeriksaan dengan acara biasa dilakukan dengan mekanisme berikut ini. Ketua PHI dalam waktu selambat-lambatnya 7 (tujuh) hari kerja setelah menerima gugatan, menetapkan majelis hakim yang terdiri dari seorang hakim karier dan 2 (dua) orang hakim ad hoc. Selambat-lambatnya 7 (tujuh) hari kerja terhitung sejak penetapan majelis hakim, ketua majelis hakim menetapkan hari sidang pertama. Untuk memulai sidang pertama, petugas pengadilan memanggil penggugat dan tergugat dengan relaas panggilan pada alamat sebagaimana disebutkan di dalam surat gugatan. Panggilan dianggap sah apabila relaas disampaikan kepada yang bersangkutan pada alamat tempat tinggal atau di tempat kediaman terakhir bila alamat tempat tinggalnya tidak diketahui. Jika pihak yang dipanggil tidak berada di tempat tinggal kediaman terakhir, relaas panggilan disampaikan melalui kepala keluarahan atau kepala desa setempat. Apabila tempat tinggal maupun tempat kediaman terakhir tidak diketahui, surat panggilan ditempelkan pada tempat pengumuman di gedung Pengadilan Hubungan Industrial. Relaas panggilan merupakan dokumen yang tidak terpisahkan daam memeriksa perkara. Keabsahan panggilan sidang hanya bisa diketahui dari relaas panggilan yang terdapat didalam berkas perkara. Apabila pihak yang dipanggil belum hadir, hakim memerintahkan Juru Sita Pengganti melakukan panggilan ulang. Jika panggilan sudah dijalankan secara sah dan patut tetapi salah satu pihak tidak hadir, hakim menentukan sikap.

\section{c. Acara Pemeriksaan Cepat}

Acara Pemeriksaan Cepat diatur dalam Bab $\mathrm{V}$ tentang Penyelesaian Perselisihan Melalui Pengadilan Hubungan Industrial Paragraf 3 Pemeriksaan Dengan Acara Cepat. Ketentuan Pasal 98 dan 99 UU Nomor 2 Tahun 2004. Secara lengkap ketentuan Pasal 98 UU Nomor 2 Tahun 2004, menyatakan bahwa:

1. Apabila terdapat kepentingan para pihak dan/atau salah satu pihak yang cukup mendesak yang harus dapat disimpulkan dari alasan-alasan permohonan dari yang berkepentingan, para pihak dan/atau 
salah satu pihak dapat memohon kepada Pengadilan Hubungan Industrial supaya pemeriksaan sengketa dipercepat.

2. Dalam jangka waktu 7 (tujuh) hari kerja setelah diterimanya permohonan sebagaimana dimaksud dalam ayat (1), Ketua Pengadilan Negeri mengeluarkan penetapan tentang dikabulkannya atau tidak dikabulkannya permohonan tersebut.

3. Terhadap penetapan sebagaimana dimaksud dalam ayat (2) tidak dapat digunakan upaya hukum.

Ketentuan Pasal 99 UU Nomor 2 Tahun 2004 menyatakan, bahwa:

1. Dalam hal permohonan sebagaimana dimaksud dalam Pasal 98 ayat (1) dikabulkan, Ketua Pengadilan Negeri dalam jangka waktu 7 (tujuh) hari kerja setelah dikeluarkannya penetapan sebagaimana dimaksud dalam Pasal 98 ayat (2) menentukan majelis hakim, hari, tempat, dan waktu sidang tanpa melalui prosedur pemeriksaan.

2. Tenggang waktu untuk jawaban dan pembuktian kedua belah pihak, masingmasing ditentukan tidak melebihi 14 (empat belas) hari kerja.

Ketentuan acara cepat sesuai Pasal 98 dan 99 UU Nomor 2 Tahun 2004 identik dengan acara kort geding yaitu persidangan dengan acara singkat merupakan bagian hukum perdata. Ketentuan acara cepat dalam Pasal 98 UU Nomor 2 Tahun 2004 baru dapat dilaksanakan apabila terdapat kepentingan para pihak dan/atau salah satu pihak yang cukup mendesak yang harus dapat disimpulkan dari alasan-alasan permohonan dari yang berkepentingan, para pihak dan/atau salah satu pihak dapat mes mohon kepada PHI supaya pemeriksaan sengketa dipercepat.

UU PPHI tidak mengatur secara rinci jenis peristiwa yang dapat dikategorikan sebagai kepentingan mendesak. Ketua
Mahkamah Agung Republik Indonesia (MARI) menerbitkan Keputusan Nomor : KMA/034/SK/IV/2006. Salah satu isinya mengatakan : "yang dimaksud dengan kepentingan mendesak pada Pasal 98 ayat (1) Undang-Undang Nomor 2 Tahun 2004, anatara lain : PHK massal, terjadi huru hara yang menggangu kepentingan produksi, keamanan dan ketertiban umum. Kalau permohonan dikabulkan, pemeriksaan dengan acara cepat dilakukan tanpa mengikuti prosedur pemeriksaan acara biasa. Dalam keputusan Ketua Mahkamah Agung di atas, yang dimaksud dengan tanpa melalui prosedur pemeriksaan adalah: "sidang pemeriksaan tidak terkait pada acara perkara perdata umumnya antara lain tentang tenggang waktu pemanggilan, replik/duplik dan hal-hal lain yang dapat menghambat proses acara cepat. Persidangan harus dilakukan pada hari kerja pertama setelah kedua belah pihak dipanggil dengan tata cara pemanggilan tercepat. “

Prosedur penanganan acara cepat ini diajukan oleh para pihak kepada Ketua Pengadilan Negeri tempat PHI tersebut berada, kemudian dalam tenggang waktu 7 (tujuh) hari kerja setelah diterimanya permohonan Ketua PHI mengeluarkan penetapan tentang dikabulkannya atau tidak dikabulkannya permohonan tersebut. Apabila tidak dikabulkan, perkara perburuhan tersebut harus memenuhi acara pemeriksaan biasa. Apabila dikabulkan, Ketua Pengadilan Negeri tempat PHI tersebut berada mengeluarkan penetapan yang pada pokoknya berisikan ammar/diktum yang memperkenankan pemeriksaan dengan acara pemeriksaan secara singkat serta menentukan Majelis Hakim, hari, tempat, dan waktu sidang tanpa melalui prosedur pemeriksaan. Kemudian, tenggang waktu untuk jawaban dan pembuktian kedua belah pihak, masingmasing ditentukan tidak melebihi 14 (empat belas) hari kerja. Tentang pemeriksaan acara 
cepat, sifatnya final dan mengikat. UU PPHI melarang mengajukan upaya hukum.

\section{Pendaftaran Gugatan}

Setelah mediasi atau konsiliasi gagal menyelesaikan perselisihan, dan mediator/konsiliator telah menerbitkan anjuran maka salah satu pihak atau kedua belah pihak dapat mengajukan gugatan dengan cara mendaftarkan gugatan ke Pengadilan Hubungan Industrial. Gugatan dibuat rangkap 7 (tujuh), satu gugatan untuk tergugat, tiga gugatan una tuk Majelis Hakim dan sisanya untuk arsip. Petugas Pengadilan memx berikan nomor register perkara. Apabila penggugat diwakili oleh kuasa hukum baik kuasa hukum dari advokat/ pengacara maupun organisasi Serikat Pekerja atau Organisasi Pengusaha maka pada saat pendaftaran gugatan harus membawa dan mendaftarkan surat kuasa khusus.

\section{Sidang Pertama}

Ketentuan tentang waktu penyelesaian yang harus dilaksanakan/ dipatuhi oleh pejabat yang melakukan kekuasaan kehakiman yang merupakan salah satu karakteristik hukum acara di Pengadilan Hubungan Industrial, khususnya ketentuan waktu tentang pelaksanaan sidang pertama sebagaimana dimaksud Pasal 89 ayat (1) Undang-Undang Nomor 2 Tahun 2004 yaitu : dalam waktu paling lambat tujuh hari kerja sejak ditetapkannya majelis hakim, ketua majelis hakim harus sudah melakukan sidang pertama. Dalam praktik ketentuan yang demikian sulit dilaksanakan karena :

a. Wilayah kerja Pengadilan Hubungan Industrial Pada Pengadilan Negeri adalah meliputi satu propinsi dan Pengadilan Hubungan Industrial Pada Pengadilan Negeri terletak di ibukota propinsi sehingga apabila ada pihak yang beralamat di luar ibukota propinsi maka akan membutuhkan waktu pemanggilan secara patut oleh juru sita minimal selama 14 (empat belas) hari. b. Ada pihak perusahaan yang di wilayah kerja Pengadilan Hubungan Industrial Pada Pengadilan Negeri adalah merupakan kantor cabang, sehingga apabila gugatan ditujukan kepada kantor pusat yang terletak di luar propinsi maka membutuhkan waktu lebih lama sekitar 1 (satu) bulan.

Dalam sidang pertama yang ditanya hakim adalah hal-hal administratif yang berkaitan dengan identitas para pihak. seperti surat kuasa khusus, kartu identitas para pihak. kartu pengacara/advokat, Berita Acara Sumpah pengacara/advokad apabila penerima kuasa adalah pengacara/advokat. apabila penerima kuasa adalah pengurus serikat pekerja/serikat buruh maka harus melengkapi fotocopy dan menunjukkan aslinya.

\section{Gugatan}

Gugatan perselisihan hubungan industrial diajukan kepada Pengadilan Hubungan Industrial pada Pengadilan Negeri yang daerah hukumnya meliputi tempat pekerja/buruh bekerja. Gugatan oleh pekerja/buruh atas pemutusan hubungan kerja sebagaimana dimaksud dalam Pasal 159 dan Pasal 171 Undang-Undang Nomor 13 Tahun 2003 tentang Ketenagakerjaan, dapat diajukan hanya dalam tenggang waktu 1 (satu) tahun sejak diterimanya atau diberitahukannya keputusan dari pihak pengusaha. Pengajuan gugatan yang tidak dilampiri risalah penyelesaian melalui mediasi atau konsiliasi, maka hakim Pengadilan Hubungan Industrial wajib mengembalikan gugatan kepada pengugat. Hakim berkewajiban memeriksa isi gugatan bila terdapat kekuarangan, hakim meminta pengugat untuk menyempurnakan gugatannya. Gugatan yang melibatkan lebih dari satu pengugat dapat diajukan secara kolektif dengan memberikan kuasa khusus. Serikat Pekerja/Serikat Buruh dan organisasi pengusaha dapat bertindak sebagai kuasa hukum untuk beracara di Pengadilan Hubungan Industrial untuk mewakili anggotanya.

\section{Jawaban}


Dalam persidangan kedua, merupakan giliran tergugat untuk memberikan tanggapan atau sanggahan atas gugatan penggugat. jawaban tergugat pada umumnya berisikan: a) eksepsi, b) mengenai pokok perkara, c) gugatan balik (rekonvensi), dan d) permohonan, (petitum).

\section{Replik}

Tanggapan penggugat (replik), merupakan jawaban kembali atas jawaban tergugat, sebagai jawaban balasan dari penggugat atas segala sesuatu hal yang disampaikan oleh tergugat dalam jawabannya. Baik yang berupa eksepsi, mengenai pokok perkara, rekonvensi, maupun petitum dari tergugat. Dalam jawaban rekonvensi, pengugat menjawab sebagai tergugat dalam rekonvensi (Pasal 142 Reglement op de Rechtverordering).

\section{Duplik}

Dalam persidangan berikutnya (ketiga), giliran tergugat untuk mendapat kesempatan menjawab untuk kedua kalinya (duplik). Dalam jawaban kali ini, tergugat diberi kesempatan untuk menjawab replik dari tergugat. Dengan demikian isi jawaban kedua, merupakan tanggapan atas replik dari penggugat.

\section{Pembuktian}

Ketentuan tentang pembuktian dalam praktik Pengadilan Hubungan Industrial adalah sebagaimana yang diatur dalam hukum acara perdata yaitu Pasal 164 HIR/284 RBg. Pembuktian yang dimaksud melipuri: bukti dengan surat, bukti dengan saksi, persangkaan - persangkaan, pengakuan, dan sumpah.

\section{Kesimpulan}

Pada persidangan dengan agenda kesimpulan ini majelis mempan silahkan para pihak menyampaikan kesimpulan atas seluruh proses pe:meriksaan perkara. Kesimpulan merupakan sarana para pihak untuk menyakinkan hakim terhadap fakta dan kebenaran yang terungkap di persidangan. Hakim tidak terikat dengan kesimpulan salah satu pihak. Hakim memiliki kesimpulan sendiri atas bukti dengan surat dan bukti berupa keterangan saksi.

Setelah sidang dengan acara kesimpulan berakhir maka Majelis monunda sidang untuk pembacaan putusan. Dalam praktik sidang ditun-A da antara 1 (satu) minggu hingga 2 (dua) minggu untuk memberikan kesempatan kepada Majelis Hakim bermusyawarah dan menyusun putusan. Karakteristik hukum acara di Pengadilan Hubungan Industrial khususnya ketentuan waktu penyelesaian yang harus dilaksanakan! dipatuhi oleh pejabat yang melakukan kekuasaan kehakiman sebagai» mana diatur dalam Pasal 103 UndangUndang Nomor 2 Tahun 2004 yang menentukan bahwa Majelis hakim wajib memberikan putusan paling lama 50 hari kerja terhitung sejak sidang pertama.

\section{Pembacaan Putusan}

Sebagai tahap akhir proses perkara maka Majelis Hakim membacakan putusan. Pembacaan putusan dilakukan pada sidang yang dinyatakan terbuka untuk umum. Acara persidangan ini dapat dihadiri oleh para pihak atau salah satu pihak. Ketidakhadiran para pihak dalam praktik dapat menyebabkan tertundanya pembacaan putusan. Mengadili perkara perselisihan hubungan industrial, PHI terikat pada waktu. PHI pada tingkat pertama memutus sangketa paling lambat 50 (lima puluh) hari kerja terhitung sejak sidang pertama dilakukan. Setelah berakhir proses jawab menjawab, pembuktian dan kesimpulan, majelis hakim melaksanakan musyawarah majelis untuk menentukan putusan. Rapat musyawarah hakim bersifat rahasia. Kesimpulan rapat musyawarah dituangkan ke dalam putusan tertulis dan diucapkan dalam sidang yang terbuka untuk umum.

Merujuk pada Pasal 1868 jo Pasal 1870 KUHPerdata, R. Wiyono mengatakan putusan hakim adalah akta autentik, sehingga putusan hakim tersebut mempunyai kekuatan pembuktian yang sempurna. Putusan hakim terikat dengan format yang ditetapkan oleh undang-undang. Bila putusan PHI tidak memenuhi salah satu syarat di bawah ini, mengakibatkan putusan itu batal.

Putusan hakim terikat dengan format yang ditetapkan oleh undang-undang harus memuat : 
a. Kepala putusan berbunyi "DEMI KEADILAN BERDASARKAN KETUHANAN YANG MAHA ESA";

b. Nama, jabatan, kewarganegaraan, tempat kediaman atau tempat kedudukan para pihak yang berselisih ;

c. Ringkasan permohonan penggugat dan jawaban termohon/tergugat yang jelas

d. Pertimbangan terhadap setiap bukti dan data yang diajukan hal yang terjadi dalam persidangan selama sangketa itu diperiksa ;

e. Alasan hukum yang menjadi dasar putusan ;

f. Amar putusan tentang sangketa ;

g. Hari, tanggal putusan, nama hakim, hakim ad hoc yang memutus, nama panitera, serta keterangan tentang hadir atau tidak hadirnya para pihak dan biaya perkara ;

Ketua dan anggota majelis hakim boleh berbeda pendapat dalam menentukan putusan. Pendapat berbeda boleh dimuat dalam putusan dan menjadi bagian dari putusan yang disebut dissenting opinion (DO). Perbedaan pendapat hakim dapat dibagi dua. Pertama, perbedaan terhadap subtansi sampai amar putusan (dissenting opinion). Kedua, perbedaan pendapat hanya pada pertimbangan atau argumentasi hukum tanpa mempermasalahkan amar putusan (concuring opinion).

\section{B. Faktor-faktor apa yang menjadi kendala dalam proses penyelesaian perkara perselisihan hubungan industrial di Pengadilan Hubungan Industrial pada Pengadilan Negeri Klas IA Samarinda}

Berdasarkan ketentuan pasal 59 ayat 1 (satu) dan 2 (dua) pada pelaksanaannya penyelesaian perkara perselisihan hubungan industrial banyak menimbulkan masalah baik yang bersifat administratif maupun yang bersifat operasional sehingga penyelesaian perkara sebagaimana amanat pasal 103 Undang-Undang No. 2 Tahun 2004 yang menyatakan bahwa "Majelis Hakim wajib memberikan putusan penyelesaian perselisihan hubungan industrial dalam waktu selambat-lambatnya 50 (lima puluh) hari kerja terhitung sejak sidang pertama".

Berdasarkan dari hasil penelitian yang dilakukan penulis di Kepaniteraan Muda Pengadilan Hubungan Industrial atau Panmud PHI yang dijabat oleh Ibu Aslina Butarbutar,SH. dan hasil wawancara penulis dengan Hakim karir dan Hakim Ad Hoc yang memeriksa dan mengadili perkara perselisihan hubungan industrial yaitu Bapak Edy Toto Purba, SH.MH; Bapak Rasyid Purba, SH.MHum selaku Ketua Majelis ${ }^{8}$. serta Bapak Jumransyah SSos.MH, Ibu Ignatia Kasiartati, SH.MH. selaku anggota majelis hakim ${ }^{9}$. diperoleh fakta yang menjadi penyebab adanya beberapa kendala baik yang bersifat administratif maupun operasional sehingga penyelesaian perkara perselisihan hubungan industrial tidak dapat selesaikan dalam waktu selambat-lambatnya 50 (lima puluh) hari kerja terhitung sejak sidang pertama.

Hasil dari penelitian Penulis ada beberapa kendala baik yang bersifat administratif maupun operasional sehingga penyelesaian perkara perselisihan hubungan industrial tidak dapat selesaikan dalam waktu selambat-lambatnya 50 (lima puluh) hari kerja antara lain sebagai berikut:

\section{Pemberitahuan relaas panggilan pada para pihak.}

Terkait dengan relaas panggilan kepada para pihak, karena Pengadilan Hubungan Industrial pada setiap Pengadilan Negeri kabupaten/kota yang berada disetiap

\footnotetext{
${ }^{8}$ Edy Toto Purba, SH.MH; Rasyid Purba, SH.MHum. Hakim Karir pada Pengadilan Hubungan Industrial di PN Samarinda

${ }^{9}$ Jumransyah, SSos, MH.; Ignatia Kasiartati, SH.MH. Hakim Ad Hoc pada Pengadilan Hubungan Industrial di PN Samarinda
} 
Ibu Kota Propinsi sedangkan domisili/alamat para pihak yang ada di wilayah hukum dalam satu provinsi yang mungkin berjauhan. Hal tersebut dapat menimbulkan masalah terkait dengan relas panggilan. Relaas panggilan sebagaimana diatur dalam hukum acara perdata bahwa relaas panggilan harus diterima secara langsung oleh para pihak sehingga hal tersebut menjadi masalah apabila relaas panggilan tidak diterima oleh para pihak dikarenakan para pihak tidak ada ditempat atau pindah alamat tanpa ada pemberitahuan para pihak kepada pengadilan. Bahwa dalam prosedur pemberian relaas, pengadilan negeri hanya di izinkan menyampaikan relas pada wilayah hukum pengadilan setempat dan apabila para pihak berdomisili/bertempat tinggal di luar wilayah hukum pengadilan setempat maka relaas panggilan menggunakan relas panggilan bantuan pada pengadilan wilayah hukum setempat dimana para pihak berada.

\section{Kehadiran para pihak dalam menghadiri sidang yang sudah dijadwalkan.}

Ketidakhadiran para pihak dalam persidangan yang telah dijadwalkan dalam persidangan (cord calendar) di pengaruhi oleh letak jarak geografis, sarana transportasi, bencana alam (banjir dan longsor) dan juga kemungkinan tidak ada itikad baik dari para pihak untuk menghadiri persidangan dalam menyelesaikan perkaranya secara cepat.

\section{Jumlah majelis hakim Pengadilan}

Hubungan Industrial yang terbatas.

Berdasarkan ketentuan pasal 70 ayat 2 (dua) Undang-Undang No. 2 Tahun 2004 yang menyatakan"Untuk pertama kalinya pengangkatan Hakim Ad-Hoc Pengadilan Hubungan Industrial pada Pengadilan Negeri paling sedikit 5 (lima) orang dari unsur serikat pekerja/serikat buruh dan 5 (lima) orang dari unsur organisasi pengusaha". Pada kenyataannya sulit terpenuhi saat ini karena jumlah Hakim Ad-
Hoc Pengadilan Hubungan Industrial dari unsur serikat pekerja dan organisasi pengusaha yang lolos seleksi oleh Mahkamah Agung jumlahnya masih jauh dari kebutuhan ditambah jumlah Hakim Karir sebagai Ketua Majelis Pengadilan Hubungan Industrial yang mempunyai sertifikasi sebagai Hakim Pengadilan Hubungan Industrial juga masih minim. Berdasarkan data pada Pengadilan Negeri Klas IA Samarinda jumlah Majelis Hakim Ad Hoc yang ada adalah 3 orang dari Hakim karir, 2 orang dari unsur Serikat Pekerja/Serikat Buruh dan 1 orang dari unsur Organisasi Pengusaha, kondisi tersebut menyebabkan penyelesaian perkara hubungan industrial urang efektif dan efisien, walaupun kondisi tersebut tidak melanggar ketentuan peraturan perundangundangan yang berlaku.

\section{Banyaknya perkara pada \\ Pengadilan Negeri tingkat ibu kota provinsi yang harus diselesaikan.}

Mengingat Pengadilan Hubungan Industrial berada pada Pengadilan Negeri Kelas 1 A di ibu kota provinsi yang rata-rata jumlah perkara perdata, pidana, tindak pidana korupsi, perselisihan hubungan industrial secara keseluruhan setiap tahunnya lebih dari 2.000 perkara sedangkan jumlah hakim yang memeriksa dan mengadili perkara-perkara hanya berkisar antara 15 sampai dengan 20 orang untuk setiap Pengadilan Negeri sehingga kebutuhan hakim tidak proporsional/ideal dengan jumlah perkara yang ditangani.

\section{Pelaksanaan penyelesaian \\ Pengadilan Hubungan Industrial masih menggunakan hukum acara perdata pada hukum acara perdata peradilan umum.}

Berdasarkan pasal 57 yang berbunyi "Hukum acara yang berlaku pada Pengadilan Hubungan Industrial adalah Hukum Acara Perdata yang berlaku pada Pengadilan dalam lingkungan Peradilan Umum, kecuali yang diatur secara khusus dalam undang-undang ini"). Hukum acara yang berlaku bagi Pengadilan Hubungan Industrial adalah hukum acara perdata yang berlaku pada pengadilan dalam lingkungan Peradilan Umum, kecuali yang diatur secara 
khusus dalam Undang-Undang No. 2 Tahun 2004 sebagaimana dimaksudkan pasal 57 Undang-Undang No.2 Tahun 2004 dengan demikian maka ketentuan ini mengatur ketentuan dan prosedur beracara yang merupakan ketentuan khusus (lex specialis) dan ketentuan hukum acara perdata yang berlaku umum sehingga hukum acara perdata yang umum hanya berlaku apabila tidak diatur dalam Undang-Undang khusus tersebut.

Pada tingkat pelaksanaanya / operasional Majelis Hakim yang memeriksa dan mengadili perkara perselisihan hubungan industrial cenderung menggunakan acara perdata umum dimulainya dengan pemeriksaan legal standing para pihak gugatan, jawaban (eksepsi), putusan sela, replik, duplik, pembuktian tertulis, pemeriksaan saksi, pemeriksaan ahli, kesimpulan, dan putusan dengan demikian hal tersebut memperpanjang proses persidangan. Menurut pendapat penulis bahwa dalam pelaksanaanya/operasional Majelis Hakim yang memeriksa dan mengadili perkara perselisihan hubungan industrial seharusnya menggunakan acara perdata umum dengan acara khusus dimulainya dengan pemeriksaan legal standing para pihak gugatan, jawaban (eksepsi), putusan sela, tanpa adanya acara replik, duplik jika tidak ada eksepsi, langsung pada acara pembuktian tertulis, pemeriksaan saksi, pemeriksaan ahli, kesimpulan, dan putusan dengan demikian proses persidangan lebih cepat dan efisien.

\section{KESIMPULAN DAN SARAN}

\section{Kesimpulan}

Hukum acara yang berlaku bagi Pengadilan Hubungan Industrial adalah hukum acara perdata yang berlaku pada pengadilan dalam lingkungan Peradilan Umum, kecuali yang diatur secara khusus dalam Undang-Undang No. 2 Tahun 2004 sebagaimana dimaksudkan pasal 57 Undang-Undang No.2 Tahun 2004 dengan demikian maka ketentuan ini mengatur ketentuan dan prosedur beracara yang merupakan ketentuan khusus (lex specialis) dan ketentuan hukum acara perdata yang berlaku umum sehingga hukum acara perdata yang umum hanya berlaku apabila tidak diatur dalam Undang-Undang khusus tersebut. Pada tingkat pelaksanaanya/operasional Majelis Hakim yang memeriksa dan mengadili perkara perselisihan hubungan industrial pada Pengadilan Hubungan Industrial Samarinda cenderung menggunakan acara perdata umum dimulainya dengan pemeriksaan legal standing para pihak gugatan, jawaban (eksepsi), putusan sela, replik, duplik, pembuktian tertulis, pemeriksaan saksi, pemeriksaan ahli, kesimpulan, dan putusan dengan demikian hal tersebut memperpanjang proses pemeriksaan dan persidangan dalam menyelesaikan perkara perselisihan hubungan industrial.

Standart Operasional Prosedur (SOP) Penyelesaian Perselisihan Hubungan Industrial, sebagaimana amanat UndangUndang Nomor 13 Tahun 2003 Tentang Ketenagakerjaan dan Undang-Undang Nomor 2 Tahun 2004 tentang Penyelesaian Perselisihan hubungan industrial. Pasal 103 Undang-Undang Nomor 2 Tahun 2004 tentang Penyelesaian Perselisihan Hubungan Industrial menyatakan bahwa " Majelis Hakim wajib memberikan putusan penyelesaian perselisihan hubungan industrial dalam waktu selambat-lambatnya 50 (lima puluh) hari kerja terhitung sejak sidang pertama", belum dapat dilaksanakan dengan baik sebagaimana amanat peraturan perundang-undangan yang berlaku.

\section{Saran}

Pengadilan Hubungan Industrial pada Pengadilan Negeri Kelas IA Samarinda untuk segera dapat memenuhi jumlah hakim sesuai kebutuhan baik Hakim Karier yang bersertifikasi sebagai Hakim PHI dan penambahan Hakim Ad Hoc PHI sebagaimana ketentuan Pasal 70 ayat (2) UU No 2 Tahun 2004, serta untuk dapat lebih meningkatkan peran Panitera Muda (Pamud) yang mengurusi perkara Perselisihan Hubungan Industrial (PHI) dibantu oleh 
Panitera Pengganti (PP) yang mengurusi perkara mulai dari masuknya berkas perkara sampai dengan putusan. Di Kepaniteraan Hubungan Industrial inilah berkas perkara diberkaskan. Panitera ini bersama-sama dengan Ketua Majelis yang ditunjuk menyusun court calendar, bersama-sama dengan Para Pihak untuk menjadwalkan pemeriksaan perkaranya dan menghadirkan saksi-saksi, saksi ahli, serta memastikan para saksi dapat hadir sehingga tidak mengganggu jadwal sidang. Juga peralatan yang berbasis komputerisasi untuk dapat lebih dioptimalkan, sehingga pembuatan berita acara persidangan, baik pada sidang pendahuluan maupun sidang perkara, transkrip dan sebagainya dapat dikerjakan tepat waktu, sehingga sehingga pelaksaan persidangan dapat lebih efektif dan efisien.

Harus ada revisi terhadap UndangUndang Nomor 2 Tahun 2004 tentang Penyelesaian Perselisihan Hubungan Industrial, terutama mengenai pasal-pasal yang mengatur tentang hukum acara penyelesaian perselisihan hubungan industrial khususnya batas waktu penyelesaian perkara selama 50 hari kerja, sebagaimana amanat Pasal 103 UndangUndang Nomor 2 Tahun 2004 tentang Penyelesaian Perselisihan Hubungan Industrial menyatakan bahwa " Majelis Hakim wajib memberikan putusan penyelesaian perselisihan hubungan industrial dalam waktu selambat-lambatnya 50 (lima puluh) hari kerja terhitung sejak sidang pertama", dan secara praktek penulis mengusulkan untuk putusan penyelesaian perselisihan hubungan industrial dalam waktu selambat-lambatnya 90 (sembilan puluh) hari kerja terhitung sejak sidang pertama dan ada sanksi apabila tidak terpenuhinya batas waktu penyelesaian sebagaimana yang telah ditentukan oleh perundang-undangan. 


\section{DAFTAR PUSTAKA}

Aloysius Uwiyono, 2014, Asas-Asas Hukum Perburuhan, Jakarta, Raja Grafindo Persada.

Harahap, M. Yahya, 2015, Hukum Acara Perdata, Jakarta, Cetakan kelima belas, Sinar Grafika,.

Juanda Pangaribuan, 2017, Seluk Beluk Hukum Acara Pengadilan Hubungan Industrial, Jakarta, MISI.

Juanda Pangaribuan, 2010, Tuntunan Praktis Penyelesaian Perselisihan Hubungan Industrial, Jakarta, Bumi Intitama Sejahtera (BIS),

Juanda Pangaribuan, 2012, Aneka Putusan Mahkamah Konstitusi Bidang Hukum Ketenagakerjaan, Jakarta, Muara Ilmu Sejahtera Indonesia (MISI),

Lilik Mulyadi, 2015, Seraut Wajah Putusan Hakim Dalam Hukum Acara Perdata Indonesia, Bandung, Citra Adtya Bakti,

Lilik Mulyadi, 2009, Kompilasi Hukum Perdata Prespektif, Teoriti dan Praktik Peradilan, Bandung, Alumni.

Lilik Mulyadi dan Agus Subroto, 2011, Penyelesaian Perkara Pengadilan Hubungan Industrial Dalam Teori Dan Praktek, Bandung, PT. ALUMNI.

Mohammad Saleh, Lilik Mulyadi, 2012, Seraut Wajah Pengadilan Hubungan Industrial Indonesia, Bandung, Citra Adtya Bakti,

Marzuki, Peter Mahmud, 2006, Penelitian Hukum, Jakarta, Kencana Prenada Media Group.

Mertokusumo, Sudikno, 1993, Hukum Acara Perdata Indonesia, Jakarta Cetakan Pertama, Liberty.

Sugeng Santoso PN, 2013, Hukum Acara Pengadilan Hubungan Industrial, Gresi, Pusat Study
Hukum Perburuan Indonesia (PSHPI),

Supomo Suparman, 2009, Hukum Acara Peradilan Hubungan Industrial, Tata Cara Penyelesaian Sengketa Perburuhan, Jaarta, Jala Permata.

Soerjono Soekamto dan Sri Mamudji, 2011, Penelitian Hukum Normatif, Suatu tinjauan singkat, Jakarta, Rajagrafindo Persada

Ugo dan Pujiyo, 2012, Hukum Acara Penyelesaian Perselisihan Hubungan Industrial, Jakarta, Sinar Grafika.

Zainal Asikin, 2012, Dasar-Dasar Hukum Perburuhan, Jakarta, Raja Grafindo.

\section{Peraturan Perundang - undangan}

1. Undang-Undang Dasar Negara Republik Indonesia Tahun 1945,

2. RV, (Reglement op de Burgerlzjke Recbtworderring Voorde Raden van Justitie op Java en het Hoaggerechtshof van Inebnesie, Alsmede voor de Residentie-gerechten op Java en Madoera) (Stb. 1847 Nomor 52 jo. Stb. 1849 Nomor 63).

3. Burgerljke Wetboek voor Indonesia (BW)

4. $\quad \mathrm{RBg}$ (Reglement Buitengewesten,) Staatsblad 1927 Nomor 227

5. HIR (Herzien Inlandsch Reglement), Staatsblad 1941 No. 44

6. Undang-Undang Nomor 21 Tahun 2000 tentang Serikat Pekerja/ Serikat Buruh, Lembaran Negara Republik Indonesia Tahun 2000 Nomor 131,

7. Undang-Undang Nomor 13 Tahun 2003 Tentang Hukum Ketenagakerjaan, Lembaran Negara Republik Indonesia Tahun 2003 Nomor 39,

8. Undang-Undang Nomor 18 Tahun 2003 tentang Advokat, , Lembaran Negara Republik Indonesia Tahun 2003 Nomor 49, 
9. Undang-Undang Nomor 2 Tahun 2004 Tentang Penyelesaian Perselisihan Hubungan Industrial, Lembaran Negara Republik Indonesia Tahun 2004 Nomor 6,

10. Undang-Undang Nomor 5 Tahun 2004 Perubahan atas Undang Undang-Nomor 14 tahun 1985 tentang Mahkamah Agung, Lembaran Negara Republik Indonesia Tahun 2004 Nomor 9,

11. Undang-Undang Nomor 8 Tahun 2004 tentang Perubahan atas UndangUndang Nomor 2 Tahun 1986 Tentang Peradilan Umum, Lembaran Negara Republik Indonesia Tahun 2004 Nomor 34,

12. Undang-Undang Nomor 49 Tahun 2009 tentang Perubahan Kedua atas Undang-Undang nomor 2 tahun 1986 Tentang Peradilan Umum, Lembaran Negara Republik Indonesia Tahun 2009 Nomor 158 ,

13. Peraturan Pemerintah Pengganti Undang-Undang Nomor 1 Tahun 2005 tentang Penangguhan Mulai Berlakunya Undang-Undang Nomor 2 Tahun 2004,

14. Peraturan Pemerintah No. 41 Tahun 2004 tentang Tata Cara Pengangkatan dan Pemberhentian Hakim Ad Hoc Pengadilan Hubungan Industrial,

15. Kepmenakertrans No Kep. 16/Men/2001 tentang Tata Cara Pencatatan Serikat Pekerja/Serikat Buruh,

16. Permenakertrans No. Per.0I/MEN/XII/2004 tentang Tata Cara Seleksi Calon Hakim Ad-Hoc Pengadilan Hubungan Industrial,

\section{Sumber laiinya}

Hery Rahyubi, 2016, Pengertian Metodologi Penelitian Menurut Para Ahli, http:/perpussekolah.com/2016, diakses tanggal 20 Oktober 2017, pukul 16.15.

PN Samarinda, Sistim Informasi Penelusuran Perkara, http:/sipp.pnsamarinda.go.id/2017, diakses tanggal 10 Oktober 2017, pukul 15.00 